\title{
FEATURE
}

\section{Soil organic matter content and crop yield}

\author{
Rattan Lal
}

$\mathrm{M}$

ost agricultural soils are depleted of their soil organic matter (SOM) reserves. A severe loss of SOM content may degrade soil functionality, its capacity for provisioning of essential ecosystem services, and soil health. Therefore, restoration of SOM content in soils of agroecosystems may reverse the degradation trends, enhance ecosystem services (Banwart et al. 2015), and advance Sustainable Development Goals of the United Nations. (Lal et al. 2018a). Increase in SOM content may also partially replace the use of chemical fertilizers and supplemental irrigation, while restoring the environment.

Some critical questions to be objectively addressed regarding the restoration of SOM include the following:

1. Is there a critical limit or range of SOM content for soils of temperate and tropical climates below which the crop yield declines?

2. If such a limit/range can be established, what are its principal determinants?

3. Can an increase in SOM content of a severely depleted soil lead to increase in crop yield under both nutrient/water limiting and sufficient conditions?

4. Can any positive impact of increase in SOM content be masked by use of chemical fertilizers and supplemental irrigation?

5. Is restoration of SOM content a resource-saving (i.e., land, water, energy) option?

Therefore, the objective of this article is to deliberate the impacts of SOM content on crop yield under diverse climate, soil, land use, and management systems.

\section{SOIL ORGANIC MATTER CONTENT AND SOIL HEALTH}

Healthy soils are important to growing healthy crops, raising healthy animals, and supporting a healthy human population through nutritionally balanced diets and environmentally healthy habitats. Favorable SOM content is critical to attaining such a vital interconnectivity. The importance of SOM content to crop yield has been known to ancient civilizations for millennia (Manlay et al. 2007), and to soil scientists for at least two centuries (Feller et al. 2012). In the modern era, Allison (1973) vividly described the significance of SOM content to crop production, which paved the way for a growing interest in the study of global terrestrial soil organic carbon (SOC) sequestration (Feller and Bernoux 2008; Lal et al. 2018b), and processes affecting its stabilization (Six et al. 2006; Dungait et al. 2013; Paul 2016).

SOM content affects crop yield through its role in enhancing and sustaining soil quality (Reeves 1997) and soil health (Lal 2016). SOM content is intricately interlinked with other physical, chemical, and biological properties and processes. A long-term study in eastern Europe (the Czech Republic, Slovakia, and Poland) indicated that regular applications of organic manure and of manure plus chemical fertilizers optimized soil quality, stabilized crop yield, and enhanced adaptation to climate change (Menšík et al. 2019).

SOM content is a critical indicator of soil health through positive impact on soil properties and processes (Doran and Zeiss 2000). In the context of agronomic productivity, two key properties impacted by SOM content are (1) plant available water capacity (PAWC) and (2) plant available essential nutrients, especially nitrogen $(\mathrm{N})$.

Plant Available Water Capacity. SOM content affects aggregation (Kemper and Koch 1966), porosity and pore size distribution, and relative proportion of retention pores that retain water at field moisture capacity. For the 50-year period between 1940 and 1990, the general consensus among soil physicists had been that SOC increases water retention both at field capacity and at permanent wilting point with no net gains in PAWC (Feustal and Byers 1936; Baver 1940; Petersen et al. 1968).

Presently, however, there are two views about the impact of SOM content on PAWC: (1) that it has minor or no impact, and (2) that it has a major impact. In UK soils, Gregory et al. (2009) reported that reduction in SOM content from 7\% to $3 \%$ can reduce soil water retention by up to $10 \%$. Similar observations on decline of water retention by decrease in SOM content were reported by Johnston et al. (2008). Decline in PAWC by reduction in SOM content is partly attributed to decline in aggregate stability. Bauer and Black (1992) reported that the loss of soil productivity by erosion in the northern Great Plains may be due to decline in nutrients and biological activity rather than from a decline in PAWC. On the basis of meta-analysis of 60 published studies, Minasny and McBratney (2018) reported that increase in SOM content has a small effect on PAWC.

However, there are others who have reported a strong effect of SOM content on PAWC (Bouyoucos 1939; Salter and Haworth 1961; Salter and Williams 1963; Petersen et al. 1968; Bryant 2015). Hudson (1994) reported highly significant positive correlations between SOM content and PAWC for a range of soil textural groups and concluded that in all textural groups, as SOM content increased from $0.5 \%$ to $3 \%$, PAWC of soil more than doubled.Williams et al. (2016) recommended investing in restoration of SOM content to enhance PAWC and mitigate downside risks and volatility in rainfed corn (Zea mays L.) in the United States. In Sierra Nevada, California, United States, Ankenbauer and Loheide II (2017) reported that increase in water retention by SOM contributes as much as $8.8 \mathrm{~cm}$ (3.46 in) to transpiration, or 35 additional water stress-free days. Even if the increase in PAWC by increase in SOM content is small, it may be of critical importance to crop growth between periods of rainfall, especially in dryland farming (Johnston 1986).

Rattan Lal is a distinguished university professor of soil science and is the director of the Carbon Management and Sequestration Center at The Ohio State University, Columbus, Ohio. 
Plant Available Nutrients. Increase in SOM content can also affect crop yield by supplying plant nutrients, especially under nutrient-limiting environments, and with low inputs of chemical fertilizers. Bauer and Black (1992) attributed the decline in productivity of degraded soils to decline in nutrients. Schjønning et al. (2018) reported a positive effect of SOM on reduction of mineral $\mathrm{N}$ needed to obtain the potential crop yield and concluded that SOM does add to crop production other than what can be attributed to nutrient supply capacity.

It is the nutrient supplying capacity of SOM upon its decomposition that has raised the question of hoarding/saving it versus using it (Janzen 2006). If the hoarding versus saving role of SOM is attributed to different fractions (fast cycling versus slower cycling) (Wood et al. 2016), then such a differential response of different fractions would resolve this seemingly apparent conflict. In the United Kingdom, Johnston et al. (2008) observed that the loss of SOM content can reduce the exchange of some essential plant nutrients ( $\mathrm{N}$, phosphorus $[\mathrm{P}]$, and sulfur $[\mathrm{S}])$, and increase of SOM content can supply N, P, and S for plant growth (Johnston 1986). SOM content also affects nutrient supply by increasing the cation exchange capacity, especially in soils of the tropics (Ramos et al. 2018). A severe loss of SOM can also lead to release of some toxic elements because of decline in chelation and adsorption capacity of soil (Griffiths et al. 2005; Gregory et al. 2015). Under semiarid environments in China, Liu and Zhou (2017) concluded that chemical fertilizers alone are not sufficient for achieving high yield, and they recommended that adding manure is essential to improving soil fertility. Synergistic effects of manuring and chemical fertilizers on wheat (Triticum aestivum L.)/cereal yield have also been reported by others (Arrieche-Luna and Ruiz-Dager 2010; Aula et al. 2016).

\section{SOIL ORGANIC MATTER CONTENT AND CROP YIELD}

Because of numerous complex and interacting factors, it is also difficult to establish a direct cause-effect relationship between crop yield and SOM content. Under field conditions, where crop yield is affected by numerous factors including biotic and abiotic stresses, the direct cause-effect relationship is also confounded by the mutual enhancement of crop yield and the SOM content. The data in table 1 on cotton (Gossypium hirsutum L.) yield from a longterm experiment in Auburn, Alabama, United States, is a pertinent example of the complexities involved. Apparently, the SOC content and cotton yield (from 1986 to 1995) are highly correlated (see figure 1). However, the beneficial effects of rotation, cover cropping, and fertilizer $\mathrm{N}$ use cannot be isolated from those of the increase in SOC content, and such effects must be accounted for. A global meta-analysis performed by Oldfield et al. (2019) indicated potential yield increases of $10 \% \pm 11 \%$ for maize and $23 \% \pm 37 \%$ for wheat with increase in SOM content. Oldfield and colleagues concluded that enhancing SOM stocks in degraded soils, and in those where a large yield gap exists, can narrow the yield gap. These yield increases amount to abridging the yield gap of 30\% for maize and 55\% for wheat, while also reducing the fertilizer inputs by $5 \%$ to $7 \%$. Oldfield and colleagues also observed that higher concentrations of SOC are associated with greater crop yields up to an SOC concentration of $2 \%$, and that led to decreased inputs of fertil-

\section{Table 1}

Effect of soil organic carbon (SOC) concentration on yield of cotton in the Old Rotation Experiment, Auburn, Alabama, United States (adapted from Reeves [1997]).

\begin{tabular}{|c|c|c|c|}
\hline \multirow[b]{2}{*}{ Treatment } & \multirow[b]{2}{*}{ SOC content (g kg-1) } & \multicolumn{2}{|c|}{ Mean cotton yield $\left(\mathrm{kg} \mathrm{ha}^{-1}\right)$} \\
\hline & & 1896 to 1905 & 1986 to 1995 \\
\hline \multicolumn{4}{|l|}{ Continuous cotton } \\
\hline - No legume cover crop & 3.9 & 896 & 1,042 \\
\hline • Legume cover crop & 7.5 & 963 & 2,498 \\
\hline • Fertilizer $N *$ & 5.4 & - & 2,083 \\
\hline \multicolumn{4}{|l|}{ 2-year rotation } \\
\hline - Legume cover crop & 8.2 & 974 & 2,565 \\
\hline $\begin{array}{l}\text { - Legume cover crop } \\
+ \text { fertilizer } N^{*}\end{array}$ & 10.0 & 997 & 2,867 \\
\hline 3-year rotation & 10.1 & 829 & 2,509 \\
\hline
\end{tabular}

*Fertilizer nitrogen $(\mathrm{N})=134 \mathrm{~kg} \mathrm{ha}^{-1} \mathrm{y}^{-1}$.

\section{Figure 1}

Effect of soil organic carbon (SOC) concentration on yield of cotton in the Old Rotation Experiment, Auburn, Alabama, United States (adapted from Reeves [1997]).

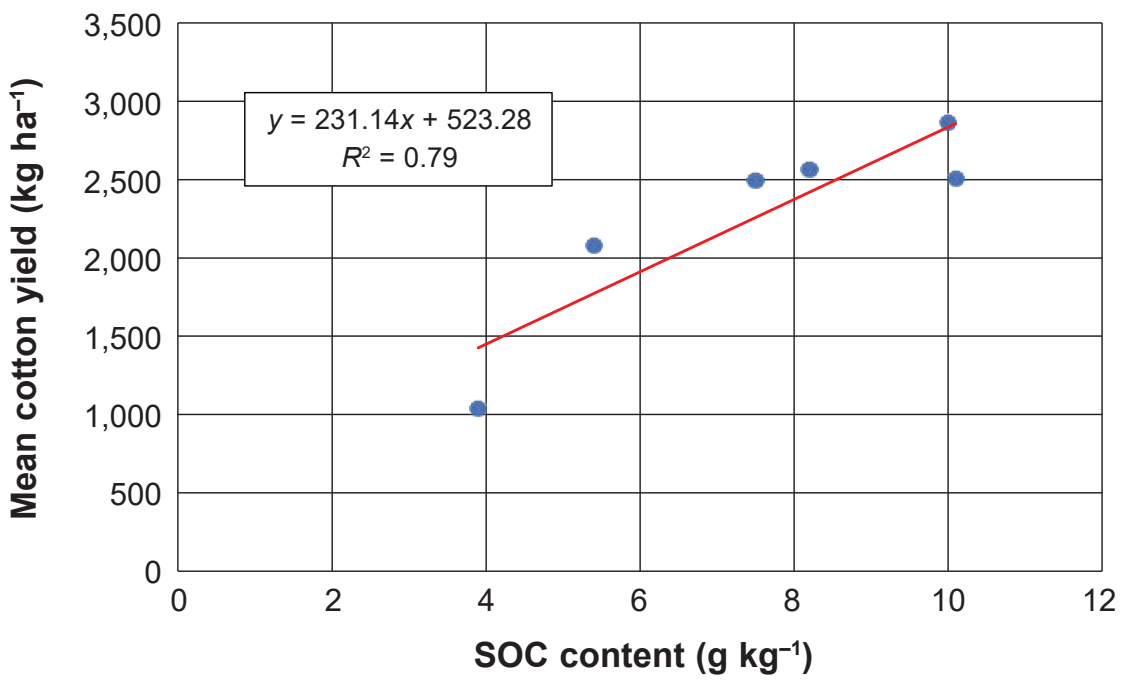


izer and irrigation. In Denmark, Ghaley et al. (2018) concluded that SOC level had a significant effect on grain yield of wheat and aboveground biomass at only 0 to $100 \mathrm{~kg} \mathrm{~N} \mathrm{ha}^{-1}$ (0 to $89.2 \mathrm{lb} \mathrm{N} \mathrm{ac}^{-1}$ ), and its effect decreased with increasing rates of N. Further, PAWC was also positively correlated with SOC content. It increased with increase in SOC content up until $0.7 \%$, and PAWC increase was small for the $0.7 \%$ to $2.0 \%$ SOC range (Ghaley et al. 2018). In contrast, several studies have suggested no effects of SOM content on crop yield (Oelofse et al. 2015; Wei et al. 2016; Hijbeek et al. 2017) and have supported the hypothesis that it is difficult to separate the effects of SOM on crop yield from those of nutrients (Murphy 2015) and other parameters.

\section{THRESHOLD LEVEL OF SOIL ORGANIC MATTER CONTENT IN ARABLE LANDS}

It may be difficult to establish a quantitative evidence for a critical threshold (Körschens et al. 1998; Reynolds et al. 2007; Gregory et al. 2015) of SOM content for the diverse global soils and growing conditions. Furthermore, the range of an adequate level of SOM may differ among soils, climates, management, and farming systems. However, a value of $2 \%$ of SOC content (SOC is about $50 \%$ of $\mathrm{SOM})$ in the root zone has been suggested for soils of temperate climates (Greenland 1975; Hamblin and Davies 1977; Johnston 1986; Loveland and Webb 2003; Oldfield et al. 2019), and $1.1 \%$ for soils of the tropics (Aune and Lal 1997). A few researchers argue that the threshold level may be less than $1 \%$ of SOC in some stable soils (Šeremešić et al. 2011). Others opine that it would be difficult to obtain the maximum crop yield in soil with SOC levels of less than 1\% (Kay and Angers 1999). Therefore, the threshold SOC level may be a soil/site-specific parameter, which must be established and managed because soil functionality can decline without an adequate level of SOC content (Liu et al. 2005; Gregory et al. 2015).

The threshold level and response of crop yield to SOM content also depend on the type and degree of soil degradation (figure 2). Rather than the simple process of decline in soil physical properties and

\section{Figure 2}

Different types of soil degradation with adverse impacts on soil organic matter (SOM) content.

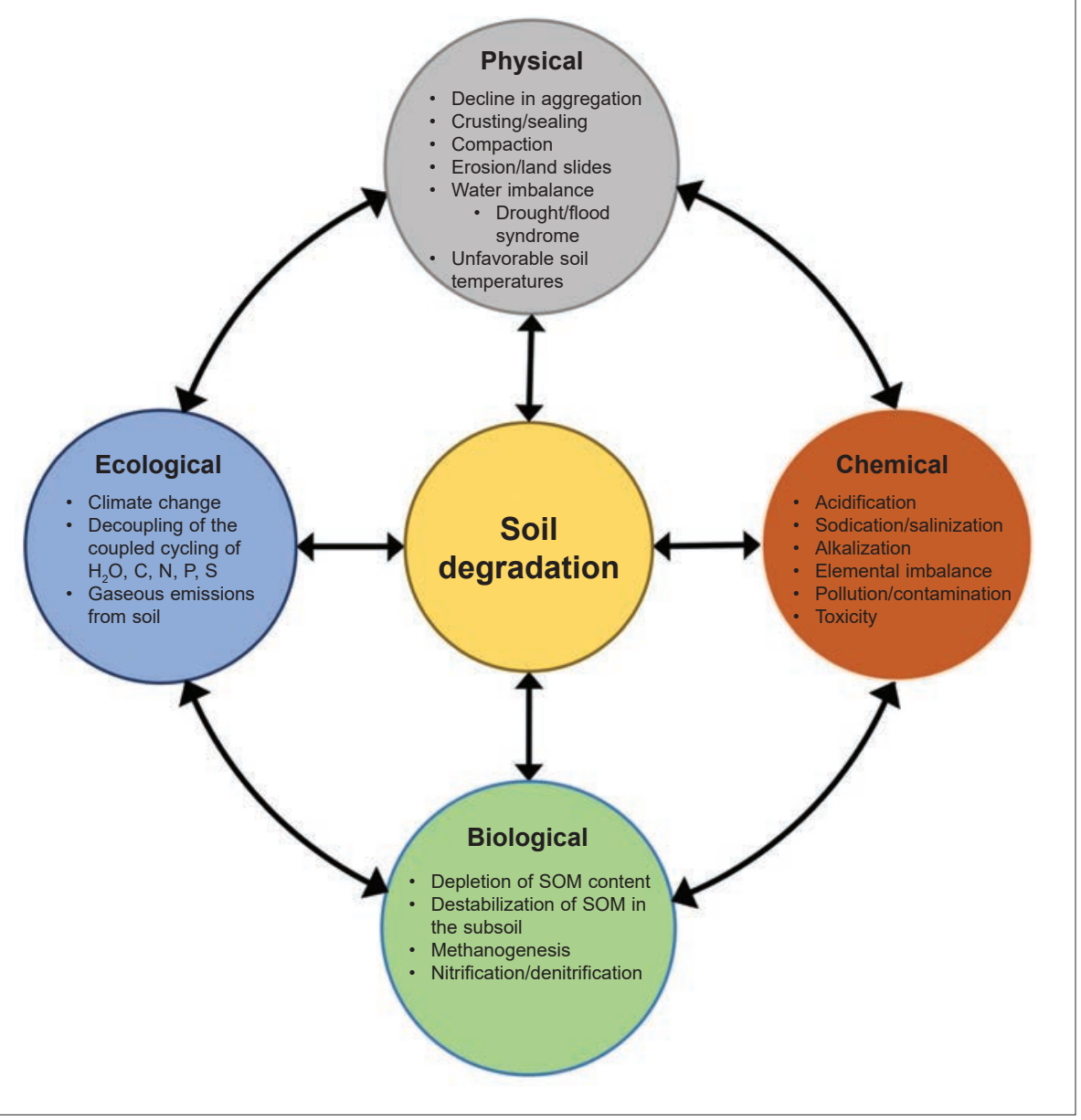

processes (i.e., aggregation, crusting, compaction, erosion, drought, and unfavorable temperature and moisture regimes), chemical characteristics (i.e., acidification, alkalization, sodication, pollution, and elemental toxicity), and biological parameters (i.e., reduction in SOM content and turnover, in activity and species diversity of soil biota, decline in microbial biomass $\mathrm{C}$, and reduction in ability of the soil to suppress pests and pathogens), the cascading effect of degradation may lead to destabilization of SOM content even in the subsoil (Rumpel and Kögel-Knabner 2011).

Figure 3 provides a conceptual basis of crop yield response to changes in SOM content in (1) depleted soil being restored, and (2) soils with a high SOM content being degraded. The graphic response in figure $3 \mathrm{a}$, with and without inputs of amendment, indicates impact on yield by the nutrient supply capacity of SOM content. The graphic response in figure $3 \mathrm{~b}$ indicates the importance of SOM on PAWC and structural tilth effects. The yield response levels off at the threshold level that varies among soils: climate, texture, and with/without input of amendment (e.g., fertilizers or manure). Note the threshold below which the yield decline is lower with than without application of amendments (figure 3a) and lower with fine-textured than that in course-textured soils (figure $3 \mathrm{~b}$ ).

In the scenario of soils with a high antecedent SOC content and depleting, the threshold level below which yield begins to decline is also lower with than without amendment (figure 3c), and lower in fine-textured than coursetextured soils (figure 3d). Thus, a critical threshold can be highly soil/site specific 


\section{Figure 3}

Hypothetical crop yield response curves to changing soil organic matter (SOM) content. ( $a$ and $b$ ) Soils depleted of their SOM content and being restored: (a) yield response with and without amendment, and (b) yield response of coarse textured and heavy textured soils. (c and d) Soils with a high antecedent SOM content and being depleted: (c) yield response with and without amendment and (d) yield response of fine versus coarse textured soils.

(a)

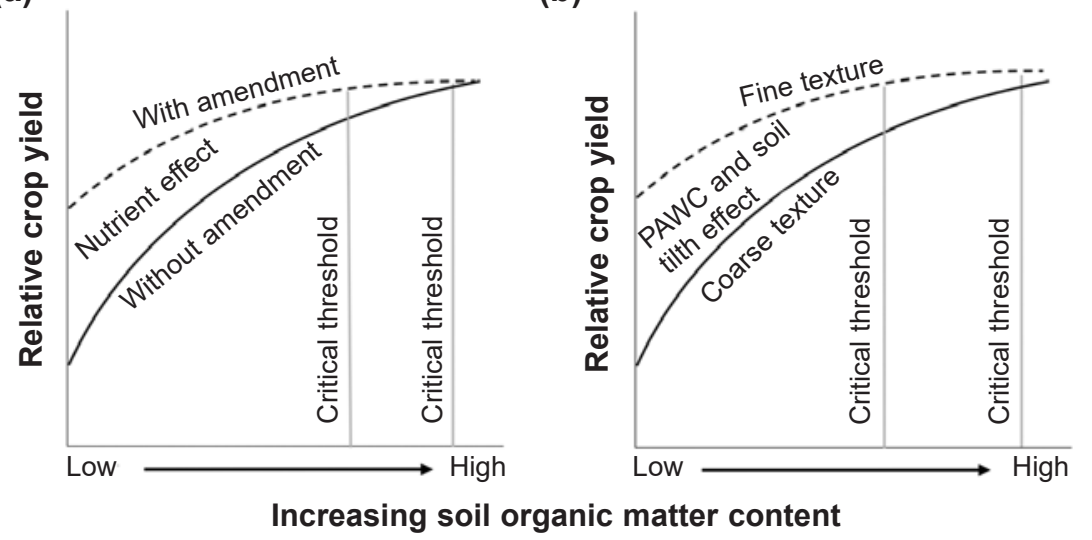

(c)

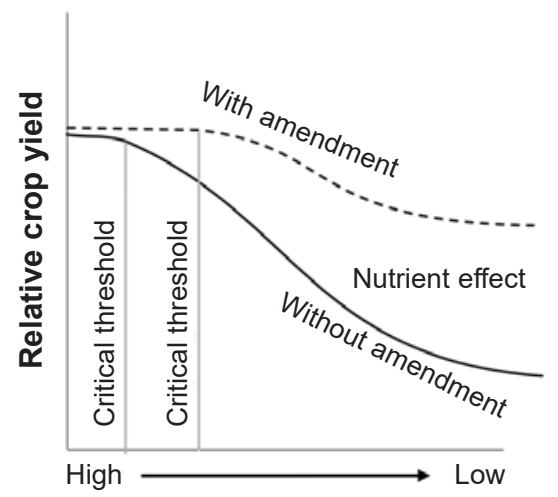

(d)

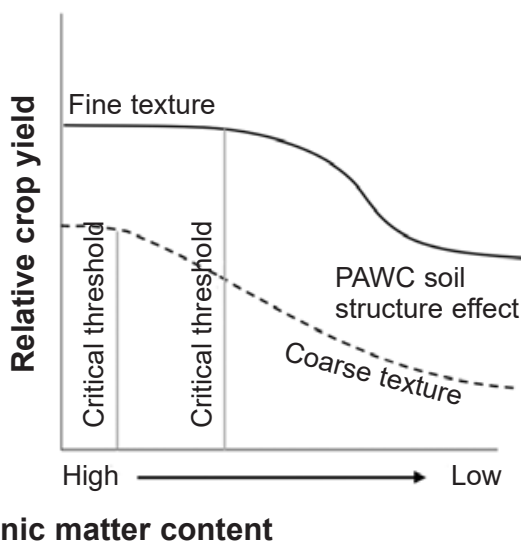

and depends on a range of inherent and managerial factors. Sustainable management of SOM content also has benefits toward saving/replacement of $\mathrm{N}$ and other fertilizers (Schjønning et al. 2018; Hijbeek et al. 2018), along with saving of some irrigation water (Williams et al. 2016; Ankenbauer and Loheide II 2017).

\section{CONCLUSIONS}

Synthesis of the available literature shows the following:

1. Increase in SOM content of depleted/ degraded soils can have a positive effect on crop yield.
2. The critical/threshold level of SOC may be about $2 \%$ in soils of the temperate zone and $\sim 1 \%$ for those of the tropics.

3. The positive yield response may be due to increase in PAWC of coarse textured soils, and due to $\mathrm{N}$ availability at low rates of $\mathrm{N}$.

4. Input of nitrogenous fertilizers and irrigation water can be saved by increasing SOM content.

5. Fertilizer and irrigation can mask the positive effects of SOM content.

Additional research is needed to establish critical limits/ranges of SOM content for diverse soils, climates, and ecoregions.

\section{REFERENCES}

Allison, F.E. 1973. Soil Organic Matter and Its Role in Crop Production,Volume 3.1st ed. Amsterdam: Elsevier Science.

Ankenbauer, K.J., and S.P. Loheide II. 2017. The effects of soil organic matter on soil water retention and plant water use in a meadow of the Sierra Nevada, CA. Hydrological Processes 31(4):891-901.

Arrieche-Luna, I.E., and M. Ruiz-Dager. 2010. Influence of inorganic and organic fertilization on microbial biomass carbon and maize yield in two soils of contrasting $\mathrm{pH}$. Agrociencia (Montecillo) 44(3):249-260.

Aula, L., N. Macnack, P. Omara, J. Mullock, and W. Raun. 2016. Effect of fertilizer nitrogen (N) on soil organic carbon, total $\mathrm{N}$, and soil $\mathrm{pH}$ in longterm continuous winter wheat (Triticum aestivum L.). Communications in Soil Science and Plant Analysis 47(7):863-874.

Aune,J.B., and R. Lal. 1997. Agricultural productivity in the tropics and critical limits of properties of Oxisols, Ultisols, and Alfisols. Tropical Agriculture 74(2):96-103.

Banwart, S., H. Black, Z. Cai, P. Gicheru, H. Joosten, R. Victoria, E. Milne, E. Noellemeyer, and U. Pascual. 2015. The global challenge for soil carbon. In Soil Carbon: Science, Management and Policy for Multiple Benefits, eds. S.A. Banwart, E. Noellemeyer, and E. Milne, 1-9. Wallingford: CABI.

Bauer, A., and A.L. Black. 1992. Organic carbon effects on available water capacity of three soils textural groups. Soil Science Society of America Journal 56(1):248-254.

Baver, L.D. 1940. Soil Physics. New York: John Wiley \& Sons, Ltd.

Bouyoucos, G.J. 1939. Effect of organic matter on the water holding capacity and the wilting points of mineral soils. Soil Science 47(1939):377-383.

Bryant, L. 2015. Organic Matter Can Improve Your Soil's Water Holding Capacity. New York: Natural Resources Defense Council. https://www.nrdc. org/experts/lara-bryant/organic-matter-canimprove-your-soils-water-holding-capacity.

Doran, J.W., and M.R. Zeiss. 2000. Soil health and sustainability: Managing the biotic component of soil quality. Applied Soil Ecology 15(1):3-11.

Dungait, J., C. Ghee, J. Rowan, B. McKenzie, C. Hawes, E. Dixon, E. Paterson, and D. Hopkins. 2013. Microbial responses to the erosional redistribution of soil organic carbon in arable fields. Soil Biology and Biochemistry 60(May 1, 2013):165-201.

Feller, C., and M. Bernoux. 2008. Historical advances in the study of global terrestrial soil organic 
carbon sequestration. Waste Management 28(4):734-740.

Feller, C., E. Blanchart, M. Bernoux, R. Lal, and R. Manlay. 2012. Soil fertility concepts over the past two centuries: The importance attributed to soil organic matter in developed and developing countries. Archives of Agronomy and Soil Science 58(1, SI):S3-S21.

Feustal, I.C., and H.G. Byers. 1936. The comparative moisture-absorbing and moisture-retaining capacities of peat and soil mixtures. In UDSA Technical Bulletin 532, 1-25. Washington, DC: United States Department of Agriculture.

Ghaley, B.B., H. Wösten, J.E. Olesen, K. Schelde, S. Baby, Y.K. Karki, C.D. Børgesen, P. Smith, J. Yeluripati, R. Ferrise, M. Bindi, P. Kuikman, J.-P. Lesschen, and J.R. Porter. 2018. Simulation of soil organic carbon effects on long-term winter wheat (Triticum aestivum) production under varying fertilizer inputs. Frontiers in Plant Science 9(2018):1158.

Greenland, D.J. 1975. Bringing the Green Revolution to the shifting cultivator. Science 190(4217):841-844.

Gregory, A.S., K. Ritz, S.P. McGrath, J.N. Quinton, K.W.T. Goulding, R.J.A. Jones, J.A. Harris, R. Bol, P. Wallace, E.S. Pilgrim, and A.P. Whitmore. 2015. A review of the impacts of degradation threats on soil properties in the UK. Soil Use and Management 31(S1):1-15.

Gregory, A., C. Watts, B. Griffiths, P. Hallett, H. Kuan, and A. Whitmore. 2009. The effect of long-term soil management on the physical and biological resilience of a range of arable and grassland soils in England. Geoderma 153(October 1, 2009):172-185.

Griffiths, B., P. Hallett, H. Kuan, Y. Pitkin, and M. Aitken. 2005. Biological and physical resilience of soil amended with heavy metal-contaminated sludge. European Journal of Soil Science 56(2005):197-206.

Hamblin, A.P., and D.B. Davies. 1977. Influence of organic matter on the physical properties of some East Anglian soils of high silt content. Journal of Soil Science 28(1):11-22.

Hijbeek, R., M.K. Ittersum, H. Berge, and A. Whitmore. 2018. Evidence review indicates a re-think on the impact of organic inputs and soil organic matter on crop yield. In 2018 IFS Agronomic Conference. Cambridge, UK: International Fertiliser Society.

Hijbeek, R., M.K. van Ittersum, H.F.M. ten Berge, G. Gort, H. Spiegel, and A.P. Whitmore. 2017. Do organic inputs matter - A meta-analysis of additional yield effects for arable crops in Europe. Plant and Soil 411(1):293-303.
Hudson, B.D. 1994. Soil organic matter and available water capacity. Journal of Soil and Water Conservation 49(2):189-194.

Janzen, H.H. 2006. The soil carbon dilemma: Shall we hoard it or use it? Soil Biology and Biochemistry 38(3):419-424.

Johnston, A.E. 1986. Soil organic matter, effects on soils and crops. Soil Use and Management 2(3): $97-105$.

Johnston, A., P. Poulton, and K. Coleman. 2008. Chapter 1. Soil organic matter: Its importance in sustainable agriculture and carbon dioxide fluxes. Advances in Agronomy 101(November 30, 2008):1-57.

Kay, B.D., and D.A. Angers. 1999. Soil Structure. In Handbook of Soil Science, ed. M.E. Sumner, 229-276. Boca Raton, FL: CRC Press.

Kemper,W.D., and E.J. Koch. 1966. Aggregate Stability of Soils from Western United States and Canada. In USDA Technical Bulletin 171386. Washington, DC: USDA Economic Research Service.

Körschens, M., A. Weigel, and E. Schulz. 1998. Turnover of soil organic matter (SOM) and long-term balances - tools for evaluating sustainable productivity of soils. Zeitschrift für Pflanzenernährung und Bodenkunde 161(4):409-424.

Lal, R. 2016. Soil health and carbon management. Food and Energy Security 5(4):212-222.

Lal, R., R. Horn, and T. Kosaki. 2018a. Soil and Sustainable Development Goals. Stuttgart: Catena-Scheizerbart.

Lal, R., P. Smith, H.F. Jungkunst, W.J. Mitsch, J. Lehmann, P.K.R. Nair, A.B. McBratney, J.C. de Moraes Sa, J. Schneider, Y.L. Zinn, A.L.A. Skorupa, H.-L. Zhang, B. Minasny, C. Srinivasrao, and N.H. Ravindranath. 2018b. The carbon sequestration potential of terrestrial ecosystems. Journal of Soil and Water Conservation 73(6):145A-152A, doi:10.2489/jswc.73.6.145A.

Liu, C.-A., and L.-M. Zhou. 2017. Soil organic carbon sequestration and fertility response to newly-built terraces with organic manure and mineral fertilizer in a semi-arid environment. Soil and Tillage Research 172(2017):39-47.

Liu, X., S. Herbert, A. Hashemi, X. Zhang, and G. Ding. 2005. Effects of agricultural management on soil organic matter and carbon transformation - A review. Plant, Soil and Environment 56(12):531-543.

Loveland, P., and J. Webb. 2003. Is there a critical level of organic matter in the agricultural soils of temperate regions: A review. Soil and Tillage Research 70(1):1-18.

Manlay, R.J., C. Feller, and M.J. Swift. 2007 Historical evolution of soil organic matter con- cepts and their relationships with the fertility and sustainability of cropping systems. Agriculture, Ecosystems \& Environment 119(3):217-233.

Menšík, L., L. Hlisnikovsky, and E. Kunzová. 2019. The state of the soil organic matter and nutrients in the long-term field experiments with application of organic and mineral fertilizers in different soil-climate conditions in the view of expecting climate change. In Organic Fertilizers: History, Production and Applications, eds. M. Larramendy and S. Soloneski, 1-29. London: IntechOpen.

Minasny, B., and A.B. McBratney. 2018. Limited effect of organic matter on soil available water capacity. European Journal of Soil Science 69(1):39-47.

Murphy, B.W. 2015. Impact of soil organic matter on soil properties - a review with emphasis on Australian soils. Soil Research 53(6):605-635.

Oelofse, M., B. Markussen, L. Knudsen, K. Schelde, J. Olesen, L. Jensen, and S. Bruun. 2015. Do soil organic carbon levels affect potential yields and nitrogen use efficiency? An analysis of winter wheat and spring barley field trials. European Journal of Agronomy 66(May 1, 2015):62-73.

Oldfield, E., M. Bradford, and S. Wood. 2019. Global meta-analysis of the relationship between soil organic matter and crop yields. Soil 5(January 15, 2019):15-32.

Paul, E.A. 2016. The nature and dynamics of soil organic matter: Plant inputs, microbial transformations, and organic matter stabilization. Soil Biology and Biochemistry 98(2016):109-126.

Petersen, G.W., R.L. Cunningham, and R.P. Matelski. 1968. Moisture characteristics of Pennsylvania soils: II. Soil factors affecting moisture retention within a textural class-silt loam. Soil Science Society of America Journal 32(1968):866-870.

Ramos, F.T., E.F.G. de C. Dores, O.L. dos S. Weber, D.C. Beber, J.H. Campelo Jr., and J.C. de S. Maia. 2018. Soil organic matter doubles the cation exchange capacity of tropical soil under no-till farming in Brazil. Journal of the Science of Food and Agriculture 98(9):3595-3602.

Reeves, D.W. 1997. The role of soil organic matter in maintaining soil quality in continuous cropping systems. Soil and Tillage Research 43(1):131-167.

Reynolds, D., C. Drury, X. Yang, C.A. Fox, C. Tan, and T.Q. Zhang. 2007. Land management effects on the near-surface physical quality of a clay loam soil. Soil and Tillage Research (October 1, 2007):316-330.

Rumpel, C., and I. Kögel-Knabner. 2011. Deep soil organic matter-A key but poorly understood component of terrestrial C cycle. Plant and Soil 338(1):143-158. 
Salter, P.J., and F. Haworth. 1961. The available-water capacity of a sandy loam soil. Journal of Soil Science 12(2):326-334.

Salter, P.J., and J.B. Williams. 1963. The effect of farmyard manure on the moisture characteristic of a sandy loam soil. Journal of Soil Science 14(1):73-81.

Schjønning, P., J.L. Jensen, S. Bruun, L. Jensen, B. Christensen, L. Munkholm, M. Oelofse, S. Baby, and L. Knudsen. 2018. The role of soil organic matter for maintaining crop yields: Evidence for a renewed conceptual basis. Advances in Agronomy 150(January 1, 2018):35-79.

Šeremešić, S., M.D,I. Đalović, T. Zeremski, and J. Ninkov. 2011. Management of soil organic carbon in maintaining soil productivity and yield stability of winter wheat. Plant Soil and Environment 57(5):201-206.

Six, J., S.D. Frey, R.K. Thiet, and K.M. Batten. 2006. Bacterial and fungal contributions to carbon sequestration in agroecosystems. Soil Science Society of America Journal 70(2):555-569.

Wei, W., Y. Yan, J. Cao, P. Christie, F. Zhang, and M. Fan. 2016. Effects of combined application of organic amendments and fertilizers on crop yield and soil organic matter: An integrated analysis of long-term experiments. Agriculture, Ecosystems \& Environment 225(2016):86-92.

Williams, A., M.C. Hunter, M. Kammerer, D.A. Kane, N.R. Jordan, D.A. Mortensen, R.G. Smith, S. Snapp, and A.S. Davis. 2016. Soil water holding capacity mitigates downside risk and volatility in US rainfed maize: Time to invest in soil organic matter? PLOS ONE 11(8):e0160974.

Wood, S.A., N. Sokol, C.W. Bell, M.A. Bradford, S. Naeem, M.D. Wallenstein, and C.A. Palm. 2016. Opposing effects of different soil organic matter fractions on crop yields. Ecological Applications 26(7):2072-2085. 